\title{
ARE BUREAUCRATS REALLY PAID LIKE BUREAUCRATS?
}

\author{
Glenn Boyle*, Scott Rademaker** \\ * Department of Economics and Finance, University of Canterbury \\ ** Department of Economics and Finance, University of Canterbury
}

\begin{abstract}
In an influential paper, Hall and Liebman (QJE, 1998) ask if senior corporate executives are really paid like bureaucrats, and conclude that they are not. In this paper, we ask if senior public service bureaucrats are really paid like bureaucrats, and conclude that they too are not. However, there is an important difference: whereas the Hall and Liebman executives face high-powered performance incentives, the bureaucrats in our sample are rewarded for expanding the size of the organisations they manage. While we cannot definitively rule out the possibility that this indicates efficient compensation of bureaucrats who provide more and better services, or face greater job complexity, the balance of our evidence is more consistent with the idea that the senior public servants in our sample are, on average, rewarded for 'empire-building', consistent with the public choice view of bureaucracy.
\end{abstract}

Keywords: Bureaucrats, Remuneration, Motivation, Incentives, Empire Building JEL classification: G34, J33

Acknowledgement

For helpful comments, we are grateful to Henk Berkman, Claire Matthews, Pascal Nguyen, Helen Roberts, and session participants at the New Zealand Finance Colloquium (Dunedin) and the Financial Markets and Corporate Governance Conference (Wellington). Thanks also to Rohan Boyle for valuable research assistance, to NZ Transport Agency and Quotable Value for data, and to the University of Canterbury College of Business and Economics IRDF programme for funding support. However, any remaining errors, ambiguities or misinterpretations are entirely our responsibility.

Minister, we don't measure our success by results, but by activity. And the activity is considerable. And productive. These 500 people are seriously overworked-the full establishment should be 650.

Sir Humphrey Appleby (quoted in Lynn and Jay, 1984)

\section{INTRODUCTION}

In an influential paper, Hall and Liebman (1998) ask if senior corporate executives (CEOs) are really paid like bureaucrats, and conclude that they are not. In this paper, we ask if senior bureaucrats are really paid like bureaucrats, and conclude that they too are not.

The research literature on corporate CEO compensation is dominated by two competing explanations for observed pay structures: efficient contracting and managerial power. ${ }^{10}$ The former views executive compensation as a mechanism for providing CEOs with the optimal set of incentives ('pay-for-performance'), and hence as a solution to the underlying agency problem. The latter sees executive compensation as the product of rentseeking by self-interested and opportunistic CEOs, and hence as a symptom of the agency problem. Many papers have tested these contrasting positions - see, for example, the surveys by Frydman and Jenter

\footnotetext{
${ }^{10}$ For recent discussions on efficient contracting, see Edmans and Gabaix (2009) or Murphy (2012). The managerial power view is well summarized in Bertrand and Mullainathan (2000) and Bebchuck and Fried (2004).

${ }^{11}$ As Frydman and Jenter note, both hypotheses find support in the data but neither clearly dominates the other.
}

(2010), and Murphy (2012). ${ }^{11}$

By contrast, very little is known about the compensation of senior bureaucrats. ${ }^{12}$ This almost certainly reflects the traditional view of bureaucrats as having strong intrinsic motivation and weak monetary incentives - see, for example, Prendergast (2007). However, public choice theorists (e.g., Niskansen, 1975; Mueller, 2003) argue that bureaucrats are self-interest maximizers who seek to advance their goals by fostering the growth of their organization. An implication of this view is that a failure to align incentives is likely to result in rent extraction by bureaucrats.

In this paper, we examinine the pay arrangements for a sample of high-level bureau-crats: the head managers ('CEOs') of local government agencies in New Zealand (NZ). These agents are employed to lead large bureaucratic organizations responsible for providing services to, and collecting revenue from, city- or district-based communities. Analogous to the corporate finance literature, we look for evidence of agency considerations (efficient contracting or rent extraction) in the remuneration of these bureaucracy-CEOs. One difficulty in doing so is the lack of an obvious performance measure, akin to stock price for corporate CEOs. One possible measure is economic growth in the CEO's region; this has obvious parallels to stock price (or return-on-assets)

\footnotetext{
${ }^{12}$ In the only study we are aware of that deals directly with bureaucrat remuneration, Johnson and Libecap (1989) examine the salaries of United States federal government employees. However, their sample includes a large number of junior bureaucrats whose pay dynamics are likely to be quite
} different to those of their superiors. 
and could be justified on the grounds that it captures CEO success in reducing red tape, attracting financial and human capital, and fostering a business-friendly environment. However, regional economic growth almost certainly picks up a number of other factors as well, making it a somewhat noisy performance measure.

An alternative measure of performance is the quantity of revenue collected by local governments from the citizens they administer, i.e., 'taxes'. This has three appealing features. First, revenue obligations to governments are clearly of direct relevance to citizens, i.e., all else equal, the more they pay to government the lower their disposable income and hence their utility. ${ }^{13}$ As a result, revenue collection constitutes a natural 'performance' measure for local government CEOs. Second, the amount of revenue collection is at least partly under the control of CEOs; although elected representatives make the final decision, the spending and financing plans they consider are drafted by bureaucrats, who therefore set the parameters of the debate. Third, the relationship between CEO pay and government revenue collection neatly distinguishes between the efficient contracting and rent seeking hypotheses: a negative relationship is consistent with pay being set in a manner that aligns incentives (efficient contracting); a positive relationship is suggestive of CEO 'empire-building' (rent extraction); while no relationship would indicate that the bureaucrats in our sample are indeed paid like bureaucrats.

Using 2006-2010 data, we find that bureaucrat pay is positively related to the financial burden imposed on citizens, i.e., the greater the per-capita revenue collected by local government, the greater the CEO's pay. One possible explanation for this is that greater revenue collection is necessitated by activities (e.g., infrastructure improvements) that increase the complexity of the CEO's job. To check this, we distinguish between revenue that is used to fund additional employment of bureaucracy personnel and that used for other purposes, and find that the positive link between CEO pay and government revenue collection is entirely driven by the former. In other words, senior bureaucrats are rewarded not for being frugal with taxpayer funds, but for expanding the size of the workforce they administer. Moreover, higher expenditure on bureaucracy personnel is associated with subsequent higher voter turnout in local government elections. Since the latter tends to indicate incumbent unpopularity (e.g., Niemi et al., 1999), this suggests that the higher pay extracted by CEOs of larger bureaucracies is not due to these bureaucracies providing additional services that are valued by ratepayers.

Our analysis extends a growing literature on compensation arrangements in non-corporate firms and organisations. For example, Di Tella and Fisman (2004) and Tuttle and Bumpass (2010) find a positive link between politician pay and electorate economic performance. Similarly, Cahan et al (2005) estimate a positive relationship between CEO pay and accounting performance in government-owned trading enterprises, but also report evidence of CEO entrenchment. In the health sector, Brickley and Van

\footnotetext{
${ }^{13}$ As Di Tella and Fisman (2004) point out, the opposite could be true if councils were engaged in a 'race to the bottom' competition on local taxes. However, Smith (2012) claims that NZ council revenue demands rose by $7 \%$ a year on average between 2002 and 2011 (compared to annual average inflation of $2.8 \%$ ), so destructive tax competition does not appear to have been
}

Horn (2002), Ballantine et al (2008), and Brickley et al (2010) report a variety of findings on the links between CEO pay, power and performance, with evidence suggestive of both efficient contracting and rent seeking forces being at work. In academia, Boyle (2008) finds that underpayment relative to outside opportunities has an adverse effect on research performance.

In the next section, we provide a brief description of the NZ local government sector, its activities, its legislative underpinnings, and the role of the senior bureaucrats that it employs. Section 3 outlines our hypotheses and the data used to test them, while sections 4 and 5 contain our principal results. Finally, section 6 offers some concluding remarks.

\section{NEW ZEALAND LOCAL GOVERNMENT}

The NZ local government sector consists of two tiers of agencies, known as 'councils'. The first-regional councils-are primarily concerned with water rights, natural resource management, land use planning, and other environmental issues. The second-city or district councils-administer core activities such as roads and other community infrastructure, public transport services, waste collection and disposal, natural hazard regulation, libraries, museums, reserves and other recreational facilities. The difference between city and district councils is primarily one of size: a district council can be called a city council if it has a population over 50,000 , is predominantly urban, and is a major centre of activity within its region. Title aside, they have exactly the same rights and responsibilities. Our focus in this paper is on the 73 city and district councils in NZ. ${ }^{14}$

City and district councils are governed by the Local Government Act of 2002. This defines a council's role as enabling democratic local decisionmaking and action by, and on behalf of, present and future communities. In practice, what this means is that each city or district council has a number of democratically elected representatives (known as councillors) who are supported on a day-to-day basis by a permanent bureaucracy. A council can undertake both core and commercial activities, and has the right to fund these via a combination of property-related taxes (known as 'rates') on eligible citizens (known as 'ratepayers') and borrowing.

Each council must have an appointed CEO who is responsible for providing direction and advice to councillors, implementing councillor decisions, and generally ensuring proper, effective and efficient management of the council's responsibilities to ratepayers. The CEO is, therefore, the council's senior bureaucrat. Initial appointment of each CEO is limited to a period of five years, after which reappointment for the same or shorter term is possible, but only after the position has been publicly advertised and all applicants properly considered. Remuneration is normally the responsibility of a subset of councillors who evaluate the CEO on an annual basis and assign a commensurate pay package.

Despite this business-like approach to council activities, the exact responsibilities of CEOs to

a feature of the NZ landscape during the period covered by our sample

14 By contrast, there are only 13 regional councils. The much greater population base, and the much narrower set of responsibilities, mean that the CEOs of these bureaucracies have fundamentally different jobs to the city and district council CEOs. 
ratepayers remain somewhat ambiguous. Birchfield (2004) reports one council CEO as claiming that:

We must be set up to attract (human capital) and we need to be competitive and that generally means we must keep rates low.

In other words, ratepayers prefer less revenue collection to more, and the ability to do so is a vital component of council performance. On the other hand, another council CEO quoted by Birchfield advocates a different set of priorities:

Councils aren't just about roads, rates and rubbish any more... The issues of social cohesion and environmental stewardship are as important nowadays as mowing the grass.

This view implicitly associates councils with the performance of more 'soft' tasks, which would inevitably require the employment of additional bureaucrats. This seems to be precisely what has occurred. In one celebrated case, questions from a local farmer forced a council CEO to admit that staff numbers had risen by $54 \%$, and total remuneration by 138\%, between 2005 and 2010. ${ }^{15}$ The question of interest to us is whether or not council CEOs are able to use this kind of growth to extract greater personal remuneration.

\section{HYPOTHESES AND DATA}

If council bureaucrats are intrinsically motivated by public service concerns, then their interests are perfectly aligned with the ratepayers who provide their funding and additional pay incentives are both unnecessary and inefficient. In this case, council CEO pay should primarily reflect the scale and complexity of the position, along with other factors such as cost of living. On the other hand, if council bureaucrats are motivated by self-interest-money, power, prestige, leisure opportunities-then two other possibilities arise. First, the councillors responsible for setting CEO pay may seek to align the latter's interests with those of ratepayers by rewarding actions that increase ratepayer wealth. Second, CEOs may simply seek the maximum remuneration their personal circumstances allow them to command, regardless of whether or not this is in ratepayers' interests.

Each financial year, the council bureaucracy, led by the CEO, prepares a financial budget for the year ahead, setting out planned expenditures and associated financing activities. Although elected councillors have final authority for setting this budget, the time and information advantages enjoyed by bureaucrats ensures that their plan sets the agenda for ensuing discussions, and hence is likely to be largely adopted. As a result, CEO decisions directly affect the economic well-being of ratepayers via council revenue demands: all else equal, more revenue collection by councils lowers ratepayer utility. We measure this financial burden on ratepayers as the sum of rates and new long-term borrowing (which necessitates higher future rates). If council CEOs are rewarded for frugality, then we should observe a negative relationship between CEO pay and revenue collection. On the other hand, a positive relationship between CEO pay and revenue collection could be suggestive of rent-seeking: council CEOs seek bigger budgets and empires which they

15 See $\$ 6 \mathrm{~m}$ wage bill queried", available at http://www.stu .co.nz/dominion-post/news/local-papers/horowhenua-mail/4088209/6mwage-bill-queried.

${ }^{16}$ See, for example, Fritsche and Marklein (2001), Krystalogianni et al (2004). then use to justify greater compensation

Council CEO pay may also be efficiently linked to the economic performance of the city or district they administer. While much of this broader performance is determined exogenously, CEOs are able to influence local economic activity by eliminating unnecessary regulations, reducing red tape, encouraging an investment-friendly environment, implementing necessary social welfare and anti-poverty policies, and making the city or district an attractive destination to migrants. Success in these areas could be motivated by linking pay to outcomes. To examine this idea, we would ideally use an income or unemployment per capita series for each council area. However, these are only available at the city/district level on a 5-yearly basis via the national census. Instead, we use a common indicator of economic activity that is available annually: new car registrations per capita. More buoyant economic conditions are typically accompanied by a higher rate of new car purchases, so the latter should be a reasonable proxy for the former. ${ }^{16}$ Of course, a positive relationship between CEO pay and new car registrations could also indicate rent-seeking: CEOs attempt to obtain as much compensation as they can when ratepayers are most able to afford this largesse.

These ideas can be expressed more formally in terms of a very simple model, adapted from Di Tella and Fisman (2004). Let C denote the CEO's remuneration, and assume that

$$
C=F+P(W, L, e)
$$

where $\mathrm{F}$ is a constant, $\mathrm{W}$ is per-capita wealth, $\mathrm{L}$ is the per-capita financial obligation imposed on ratepayers, and e $\geq 0$ is the 'effort' exerted by the CEO in extracting rents, via empire-building, lobbying, and so on. In words, equation (1) states that CEO pay equals the sum of a fixed component $\mathrm{F}$ (a bureaucratic salary) and a 'premium' component $P$ that depends on the CEO's performance in assisting wealth creation and minimizing the financial burden on ratepayers, together with the success of any rent-extraction efforts. We assume $\mathrm{P}_{W} \geq 0, \mathrm{P}_{\mathrm{L}} \leq 0, \mathrm{P}_{\mathrm{e}}>0$ (subscripts indicate partial derivatives), where $\mathrm{P}=\mathrm{P}_{\mathrm{W}}=\mathrm{P}_{\mathrm{L}}=\mathrm{e}=0$ if the CEO is paid as a bureaucrat. The optimal choice of e satisfies:

$$
P_{e}=1
$$

Assuming that there are diminishing returns to CEO rent-extraction efforts $\left(\mathrm{P}_{e e}<0\right)$ and that such efforts are more productive when ratepayers are financially comfortable $\left(\mathrm{P}_{\mathrm{ew}}>0\right)$ and when the council has more revenue to distribute $\left(\mathrm{P}_{\mathrm{eL}}>0\right)$, it follows from (2) that:

$$
\frac{d C}{d W}=P_{w}-\frac{P_{e W} P_{e}}{P_{e e}} \geq 0
$$

and

$$
\frac{d C}{d L}=P_{L}-\frac{P_{e L} P_{e}}{P_{e e}} \geq \leq 0
$$

Equations (3) and (4) show that CEO pay is increasing in ratepayer wealth for both

and Rua and Nunes (2005). The OECD also reports car registrations as one of its 'main economic indicators'-see http://stats.oecd.org/mei/default.asp?rev=4 
efficiency and rent extraction reasons, but the impact of revenue collection on CEO pay is ambiguous due to competing efficiency and rent extraction effects. In (3), an increase in ratepayer wealth efficiently raises bureaucrat remuneration (pay-for-performance), and also allows more rent extraction. In (4), by contrast, greater revenue collection is punished by ratepayers, but at the same time creates a bigger resource pool that can be expropriated by bureaucrats.

We investigate these issues empirically by estimating regression models of the general form:

Real CEO pay $=\alpha_{0}+\sum_{i} \beta_{i}$ Performance $_{i}+\sum_{j} \gamma_{j}$ Control $_{j}+\varepsilon$

where the control variables are city/district population, area (in square kilometers), and average house price. ${ }^{17}$ The first two capture the scale and complexity of the CEO's task while the last reflects the cost of living. All monetary variables are converted to 2005 values using the NZ consumer price index. ${ }^{18}$

Table 1. Summary statistics

Summary statistics from an unbalanced 2006-2010 panel of 280 annual observations on 69 New Zealand city and district councils. All variables are measured at the council level. CEO pay is remuneration of the council's CEO; New Cars is the number of new car registrations per head of population; Revenue Collection is the sum of rates and new borrowing per head of population; Population is the number of people living in the region administered by the council; House Price is the average house sale price; Area is the size (in square kilometres) of the region administered by the council. All monetary variables are in 2005 NZ dollars.

\begin{tabular}{|l|c|c|c|c|c|}
\hline Variable & Mean & Standard Deviation & Median & Maximum & Minimum \\
\hline Panel A: Pay and Performance Variables \\
\hline CEO Pay & $\$ 214287$ & $\$ 61474$ & $\$ 204284$ & $\$ 419719$ & $\$ 106917$ \\
\hline New Cars & 0.011 & 0.006 & 0.010 & 0.051 & 0.003 \\
\hline Revenue Collection & $\$ 851$ & $\$ 358$ & $\$ 789$ & $\$ 3013$ & $\$ 103$ \\
\hline \multicolumn{7}{|l|}{ Panel B: Control Variables } \\
\hline Population & 56923 & 76668 & 33550 & 444100 & 3770 \\
\hline House Price & $\$ 267053$ & $\$ 95518$ & $\$ 259538$ & $\$ 559857$ & $\$ 104720$ \\
\hline Area & 3917 & 4423 & 2615 & 30753 & 22 \\
\hline
\end{tabular}

To estimate equation (5), we collected data on NZ councils and CEOs between 2005 and 2010. Data on CEO pay and revenue collection appear in council annual reports. New car registrations were obtained from NZ Transport Agency while population estimates and size come from the Statistics NZ website. ${ }^{19}$ Finally, house price data were provided by Quotable Value. Our initial sample covers 73 councils and six years, yielding a panel of 438 observations. However, we lose (i) the 2005 observations due to new long-term borrowing being estimated as the annual change in long-term debt, and (ii) four councils due to one or more variables not being reported in any sample year..$^{20}$ Moreover, not all variables are available in every year for the remaining 69 councils. Our final sample is an unbalanced panel of 280 observations.

Table 1 provides some summary statistics for this sample. All variables contain considerable crosscouncil variation. For example, the typical council CEO is paid slightly over $\$ 214,000$ (consisting of salary, bonus, and other benefits such as vehicle and phone usage), but this lies within a range of $\$ 107,000$ to $\$ 420,000$. Similarly, annual council revenue demands are approximately $\$ 850$ per person on

\footnotetext{
${ }^{17}$ We also experimented with various CEO characteristics, such as gender, tenure, and background (private versus public sector internal versus external appointment). However, none of these had any explanatory power for CEO pay, or otherwise affected the results.

${ }^{18}$ This series is available from the Reserve Bank of NZ website www.rbnz.govt.nz
}

average, but individual councils charge considerably more and less than this during the sample period.

\section{RESULTS}

Table 2 contains the results we obtain from estimating various versions of equation (5). We estimate all models in $\log$ form, so the coefficient estimates have an elasticity interpretation. Column (1) includes only the control variables, which together explain an impressive $80 \%$ of the variation in council CEO remuneration. However, while population and the cost of living are both economically and statistically significant determinants of CEO pay, the effect of greater area is indistinguishable from zeroas it is in all specifications.

Columns (2) and (3) successively introduce the two 'performance' variables while column (4) includes both of them together. Council CEOs do not appear to be rewarded for buoyant economic activity in the regions they administer: new car registrations are negatively related to CEO pay, albeit not in a statistically significant manner. ${ }^{21}$ By contrast, council revenue collection is positively and significantly (at

\footnotetext{
${ }^{19}$ See www.stats.govt.nz/.

${ }^{20}$ The four omitted councils are Chatham Islands, North Shore, Otorohanga, and Papakura. We also omit the Auckland 'supercity' council as this did not come into existence until 2010.

${ }^{21}$ The results are unaffected if local new car registrations are measured relative to the national average, or lagged one year.
} 
the 5\% level) linked to CEO pay, with an elasticity (in column (3)) of 0.067 , i.e., a $10 \%$ difference in ratepayer burden is associated with a $0.67 \%$ CEO pay differential. Putting this in context, a one standard deviation change in revenue collection corresponds to an approximately $2.8 \%$ pay difference, or $\$ 6040$, on average. ${ }^{22}$ Column (5) shows that this result is robust to the inclusion of period fixed effects.

One potential problem with these models estimated from panel data is the presence of significant measurement error in some of the explanatory variables. For example, in the borrowing component of revenue collection, it is not uncommon to see large increases in long-term debt in one year followed by equally large reversals in the following year; similar year-to-year fluctuations also appear in the house price series. We are sceptical about the accuracy of such intra-variable volatility and suspect at least some of it may be attributable to reporting error or small-sample bias. If so, the effects on our regression estimates could cut both ways. On the one hand, if measurement error in long-term borrowing is positively correlated with CEO pay, then the estimated coefficient on revenue collection will be overstated. On the other hand, measurement error noise will understate the precision of that estimate. Similar concerns apply to measurement error in the house price variable.

To address this issue, we create a new data set that eliminates these year-to-year fluctuations Specifically, for each council we calculate annual averages of each variable over the sample period (reducing the sample size to 69 observations) and then re-estimate equation (5). Columns (6) and (7) report two of these models: the estimated elasticity of CEO pay to ratepayer burden is more than twice as large as in the panel data and is much more precisely estimated (now significant at the 1\% level); a one standard deviation difference in ratepayer burden now corresponds to an approximately $4.7 \%$ pay differential, or $\$ 9794$, on average..$^{23}$

The results in Table 2 reveal no evidence of council CEOs being rewarded for superior economic activity in the regions they administer, but they do offer fairly strong evidence of a positive link between CEO pay and the financial burden imposed on ratepayers. The latter finding has two possible explanations. First, it may reflect an 'efficient' pay structure, in which council CEOs are rewarded for acting in ratepayer interests. For example, the additional revenue collection could be used to provide services valued by ratepayers. Or CEOs of councils that collect large amounts of revenue may have more complex jobs. Second, it may indicate rent extraction, with council CEOs engaging in ratepayerfunded 'empire building' as a means of extracting greater remuneration.

To distinguish between these two competing explanations, consider the uses to which additional ratepayer funding might be put. On the one hand, such funding could be used to invest in additional infrastructure, greater cultural and recreational opportunities, and community 'events'-services that are desired by ratepayers and that increase the complexity of the CEO's role. On the other hand, it could be used to hire more council employees, bulking up the size of the organization controlled by the CEO. We therefore split the revenue collection variable into two components: the portion used to finance expenditure on bureaucrat employment (personnel cost) and the rest (other revenue collection), both in per-capita terms. ${ }^{24}$ If the Table 2 results reflect empire building by council CEOs, then the personnel cost variable should be the more important determinant of CEO pay. But if additional funding is used to provide services desired by ratepayers, then we should see CEO pay being more closely linked to other revenue collection.

A crucial assumption implicit in this approach is that the hiring of additional bureaucrats is contrary to ratepayer interests and not desired by them. But this may not be the case. More low-level bureaucrats may be welcomed by ratepayers because they result in shorter queues in Council offices, yield faster responses to enquiries and complaints, and allow the provision of more social services. Council CEOs would then be efficiently rewarded for providing such improvements.

Consequently, to justify our proposed procedure, we require some mechanism for identifying the popularity of a bigger council bureaucracy: to what extent do ratepayers value the employment of additional bureaucrats? In this context, a common research finding is that, in western democracies such as NZ, voter turnout in elections tends to be negatively correlated with incumbent popularity, e.g., Carsey (2000), Grofman et al. (1999), Niemi et al. (2011). Thus, if the use of public funds to pay for large council bureaucracies is on balance unpopular with ratepayers, we should observe a positive relationship between voter turnout and per-capita expenditure on the employment of council bureaucrats. On the other hand, if more bureaucrats enable the provision of more services valued by, and popular with, ratepayers, then we should observe a negative relationship.

\footnotetext{
${ }^{22}$ From Table 1, the standard deviation of revenue collection is approximately $42 \%$ of its mean. So a one

standard deviation change in revenue collection changes CEO pay by $(0.067) \times(0.42)=0.028$ on average. Applying this to the average CEO pay of $\$ 214287$ from Table 1 yields a dollar change of $\$ 6040$.

${ }^{23}$ This alternative data set also helps control for possible lagged effects. For example, if stronger economic performance (as proxied by new car registrations) feeds into CEO pay only with a year's lag, then our contemporaneous panel models will underestimate the importance of this relationship. Correspondingly, the importance of revenue collection for CEO pay may be over-
}

stated. However, by impounding any such lags in the data being analysed, columns (6) and (7) suggest such concerns are unfounded. Separate robustness tests (unreported) that explicitly allow for various lagged relationships in our panel data confirm this interpretation.

${ }^{24}$ Some councils out-source some of their personnel activities, leading to an under-statement of true personnel costs. To the extent allowed by our sources, we attempt to take account of this in constructing the personnel cost variable. Nevertheless, some measurement error surely remains, so some caution is advisable. 
Table 2. Bureaucrat Pay and Performance: Regression Results

The dependent variable is the natural log of Council CEO real pay. All explanatory variables are natural logs of those defined in Table 1. Regressions (1)-(5) are estimated from an unbalanced 2006-2010 panel of 280 annual observations; terms in parentheses are robust standard errors clustered at the council level. Regressions (6)-(7) are estimated from a cross-section based on 2006-10 annual averages of all variables; terms in parentheses are White (1980) heteroskedasticity-robust standard errors. $\left.{ }^{* *}{ }^{*}\right)$ denotes significance at the .01 (.05) level.

\begin{tabular}{|c|c|c|c|c|c|c|c|}
\hline & (1) & (2) & (3) & (4) & (5) & (6) & (7) \\
\hline Intercept & $\begin{array}{l}8.223^{* *} \\
(0.430)\end{array}$ & $\begin{array}{l}8.166^{* *} \\
(0.446)\end{array}$ & $\begin{array}{l}7.916^{* *} \\
(0.388)\end{array}$ & $\begin{array}{l}7.846^{* *} \\
(0.409)\end{array}$ & $\begin{array}{l}7.986^{* *} \\
(0.405)\end{array}$ & $\begin{array}{l}7.592^{* *} \\
(0.355)\end{array}$ & $\begin{array}{l}7.487^{* *} \\
(0.402)\end{array}$ \\
\hline Population & $\begin{array}{l}0.206^{* *} \\
(0.016)\end{array}$ & $\begin{array}{l}0.213^{* *} \\
(0.017)\end{array}$ & $\begin{array}{l}0.209^{* *} \\
(0.015)\end{array}$ & $\begin{array}{l}0.214^{* *} \\
(0.016)\end{array}$ & $\begin{array}{l}0.208^{* *} \\
(0.016)\end{array}$ & $\begin{array}{l}0.212^{* *} \\
(0.016)\end{array}$ & $\begin{array}{l}0.218^{* *} \\
(0.019)\end{array}$ \\
\hline House Price & $\begin{array}{l}0.153^{* *} \\
(0.041)\end{array}$ & $\begin{array}{l}0.159^{* *} \\
(0.043)\end{array}$ & $\begin{array}{l}0.140^{* *} \\
(0.037)\end{array}$ & $\begin{array}{l}0.147^{* *} \\
(0.039)\end{array}$ & $\begin{array}{l}0.140^{* *} \\
(0.038)\end{array}$ & $\begin{array}{l}0.121^{* *} \\
(0.039)\end{array}$ & $\begin{array}{l}0.128^{* *} \\
(0.041)\end{array}$ \\
\hline Area & $\begin{array}{l}-0.004 \\
(0.010)\end{array}$ & $\begin{array}{l}-0.006 \\
(0.010)\end{array}$ & $\begin{array}{l}-0.006 \\
(0.010)\end{array}$ & $\begin{array}{l}-0.008 \\
(0.010)\end{array}$ & $\begin{array}{l}-0.007 \\
(0.010)\end{array}$ & $\begin{array}{l}-0.006 \\
(0.008)\end{array}$ & $\begin{array}{l}-0.007 \\
(0.008)\end{array}$ \\
\hline New Cars & & $\begin{array}{l}-0.027 \\
(0.027)\end{array}$ & & $\begin{array}{l}-0.030 \\
(0.027)\end{array}$ & & & $\begin{array}{l}-0.031 \\
(0.040)\end{array}$ \\
\hline $\begin{array}{l}\text { Revenue } \\
\text { Collection }\end{array}$ & & & $\begin{array}{c}0.067^{*} \\
(0.029)\end{array}$ & $\begin{array}{c}0.068^{*} \\
(0.030)\end{array}$ & $\begin{array}{c}0.059^{*} \\
(0.029)\end{array}$ & $\begin{array}{l}0.144^{* *} \\
(0.048)\end{array}$ & $\begin{array}{l}0.149^{* *} \\
(0.050)\end{array}$ \\
\hline$N$ & 280 & 280 & 280 & 280 & 280 & 69 & 69 \\
\hline Year Fixed Effects & No & No & No & No & Yes & NA & NA \\
\hline Adjusted R2 & 0.80 & 0.80 & 0.81 & 0.81 & 0.81 & 0.88 & 0.89 \\
\hline F-statistic & $366.1^{* *}$ & $275.7^{* *}$ & $289.7^{* *}$ & $233.3^{* *}$ & $151.7^{* *}$ & $124.5^{* *}$ & $99.03^{* *}$ \\
\hline
\end{tabular}

Table 3. Bureaucrat Pay and Empire Building

The dependent variable is the natural log of Council CEO real pay. Personnel Cost is the natural log of real expenditure on Council personnel (per head of population). Other Revenue Collection is the natural log of the per-capita sum of rates and new borrowing minus Personnel Cost. All other variables are described in Table 1. Regressions (1), (2) and (4) are estimated from a 2006-10 unbalanced panel of 280 observations; Terms in parentheses are robust standard errors clustered at the council level. Regressions (3) and (5) are estimated from a cross-section based on 2006-10 averages of all variables; terms in parentheses are White (1980) heteroskedasticity-robust standard errors. ${ }^{* *}(*)$ denotes significance at the $.01(.05)$ level.

\begin{tabular}{|c|c|c|c|c|c|}
\hline & (1) & (2) & (3) & (4) & (5) \\
\hline Intercept & $\begin{array}{l}7.560^{* *} \\
(0.416)\end{array}$ & $\begin{array}{l}7.610 * * \\
(0.419)\end{array}$ & $\begin{array}{l}7.455^{* *} \\
(0.398)\end{array}$ & $\begin{array}{l}7.610^{* *} \\
(0.431)\end{array}$ & $\begin{array}{l}7.384 * * \\
(0.425)\end{array}$ \\
\hline Population & $\begin{array}{l}0.206^{* *} \\
(0.013)\end{array}$ & $\begin{array}{c}0.204 * * \\
(0.013)\end{array}$ & $\begin{array}{c}0.208^{*} \\
(0.013)\end{array}$ & $\begin{array}{l}0.204^{* *} \\
(0.014)\end{array}$ & $\begin{array}{l}0.213^{* *} \\
(0.015)\end{array}$ \\
\hline House Price & $\begin{array}{l}0.149^{* *} \\
(0.038)\end{array}$ & $\begin{array}{c}0.150 * * \\
(0.038)\end{array}$ & $\begin{array}{l}0.146^{* *} \\
(0.036)\end{array}$ & $\begin{array}{l}0.150^{* *} \\
(0.039)\end{array}$ & $\begin{array}{l}0.152^{* *} \\
(0.038)\end{array}$ \\
\hline Area & $\begin{array}{l}-0.007 \\
(0.010)\end{array}$ & $\begin{array}{l}-0.008 \\
(0.010)\end{array}$ & $\begin{array}{l}-0.004 \\
(0.008)\end{array}$ & $\begin{array}{l}-0.008 \\
(0.010) \\
\end{array}$ & $\begin{array}{l}-0.005 \\
(0.008) \\
\end{array}$ \\
\hline Personnel Cost & $\begin{array}{l}0.115^{* *} \\
(0.024)\end{array}$ & $\begin{array}{c}0.112 * * \\
(0.024)\end{array}$ & $\begin{array}{l}0.122^{* *} \\
(0.026)\end{array}$ & $\begin{array}{l}0.112 * * \\
(0.024)\end{array}$ & $\begin{array}{l}0.123^{* *} \\
(0.026)\end{array}$ \\
\hline Other Revenue Collection & $\begin{array}{c}0.012 \\
(0.008) \\
\end{array}$ & $\begin{array}{c}0.010 \\
(0.008) \\
\end{array}$ & $\begin{array}{c}0.020 \\
(0.012) \\
\end{array}$ & $\begin{array}{c}0.010 \\
(0.008) \\
\end{array}$ & $\begin{array}{c}0.021 \\
(0.012) \\
\end{array}$ \\
\hline New Cars & & & & $\begin{array}{c}0.001 \\
(0.028) \\
\end{array}$ & $\begin{array}{r}-0.023 \\
(0.036) \\
\end{array}$ \\
\hline$N$ & 280 & 280 & 69 & 280 & 69 \\
\hline Year Fixed Effects & No & Yes & NA & Yes & NA \\
\hline Adjusted R2 & 0.82 & 0.83 & 0.89 & 0.83 & 0.88 \\
\hline F-statistic & $261.8^{* *}$ & $154.3^{* *}$ & $106.9^{* *}$ & $138.4^{* *}$ & $88.21^{* *}$ \\
\hline
\end{tabular}

To determine which of these views is better supported by data, we obtained 2010 mayoral election turnout figures from the NZ Department of Internal Affairs and regressed this on average real personnel council costs during the current electoral cycle (2008-2010). ${ }^{25}$

The estimated relationship is fairly small (every $\$ 100$ increase in per-capita personnel expenditure reduces voter turnout by slightly more than one percentage point), but highly statistically significant (at the 1\% level). That is, voter turnout in NZ council elections is positively correlated with the proportion of their rates that goes on funding bureaucrat employment. While not conclusive, this provides some evidence that large council bureaucracies are

${ }^{25}$ See: http://www.dia.govt.nz/diawebsite.nsf/wpg URLServicesLocal-Elections-Local-Authority-Election-Statistics2013?OpenDocument\#four 
associated with 'services' that are not favoured by ratepayers.

Exploiting this finding, columns (1)-(3) of Table 3 report the results from decomposing the revenue collection variable into its 'personnel' and 'other' components, using both the panel (with and without year fixed effects) and period average data sets. In every specification, the coefficient estimate for the 'other' variable is economically small and statistically insignificant. By contrast, the personnel cost coefficient estimate is uniformly large and highly statistically significant (at the $1 \%$ level or better). From the panel estimates, a one standard deviation difference in personnel cost corresponds to an approximately 6.2\% (\$13296) difference in pay; the analogous figure from the period average data is $8.5 \%$ (\$17742). Council CEOs seem to be rewarded for the size of the organization they are able to create; more employees-a bigger 'empire'-evidently allows CEOs to extract additional remuneration from councillors and, hence, from ratepayers. ${ }^{26-}$

\section{ALTERNATIVE INTERPRETATIONS}

We wish to be sceptical about the results of the previous section. After all, a considerable literature emphasizes the strong public service motivations of bureaucrats (e.g. Perry and Wise, 1990; Crewson, 1997; Perry et al, 2010) and their weak financial motivations (e.g., Prendergast, 2007). In this section, we discuss some other possible interpretations of the observed positive relationship between senior bureaucrat pay and the size of their organisations.

One obvious possibility is that the personnel cost variable is partly picking up variation in ratepayer wealth, and that greater wealth leads to higher bureaucrat pay, either via a pay-forperformance mechanism or because of a desire on the part of ratepayers to maintain the CEO's relative wealth position. ${ }^{27}$ According to this view, more bureaucrat employment is not 'causing' higher CEO pay. Instead, greater ratepayer wealth simultaneously leads to (i) greater ratepayer demand for bureaucrat services and (ii) a greater willingness of ratepayers to offer higher remuneration to council CEOs. Consequently, the relationship between CEO pay and bureaucracy size is spurious.

As we have already seen, part (i) of this argument is subject to counter-evidence: higher spending on bureaucrat personnel is associated with higher voter turnout, suggesting that the higher spending is not popular. To further, and more directly, assess the wealth story, we attempt to control for variation in ratepayer wealth by including new car registrations as an additional regressor in our models. As columns (4) and (5) of Table 3 reveal, this has no effect on our previous results: the strength of the relationship between CEO pay and bureaucracy size is essentially unchanged. To the extent that new car registrations are a reasonable proxy for ratepayer wealth, it therefore seems unlikely that our results can be attributed to underlying, and unidentified, variation in such wealth.

More generally, the empire-building interpretation of our results may be incorrect due to endogeneity: it might be that councils which pay their

\footnotetext{
${ }^{26}$ This finding is foreshadowed in the model of Weatherby (1971)
}

CEOs a lot also tend to hire lots of lower-level bureaucrats. In particular, if our analysis omits a variable that is positively related to both CEO pay and council personnel cost, then our estimated relationship is biased upwards, and we cannot rule out the possibility that, within each council, CEO pay is actually negatively related to revenue collection and personnel cost, i.e., CEOs are rewarded for conserving ratepayer money.

The usual way of dealing with this problem is to isolate the within-council relationship by including council fixed effects in the regression models. Unfortunately, this is infeasible here. First, in models that include council area, the inclusion of council fixed effects results in perfect collinearity. Second, even if the area variable is excluded, the coefficient matrix is of less than full rank and hence of little value. This reflects the short nature of the time series component of our panel: each council appears only four times on average, and a sizeable number (17) appear three times or less. This is further compounded by 12 changes of CEO during the sample period.

A solution to this problem is proposed by Wooldridge (2010), who shows that the standard fixed effects estimator can be obtained in unbalanced panels by including time averages of the explanatory variables in either OLS or random effects models. The principal results from applying this procedure are straightforward. First, the personnel cost coefficient estimate is less precisely estimated; for example, in the column (1) model of Table 3, the t-statistic is 2.0, compared with 4.75 without council fixed effects. Second, the economic magnitude of personnel cost is unaffected; for example, in the column (1) model of Table 3, the coefficient estimate is 0.129 , compared with 0.115 without council fixed effects. Third, the other revenue collection coefficient estimate remains economically and statistically indistinguishable from zero. Thus, even after allowing for fixed council effects, the relationship between senior bureaucrat pay and ratepayer financial commitments loads entirely, if less precisely, onto the portion of those commitments used for the hiring more bureaucrats, and none of it loads onto the portion used for other purposes.

An alternative, less formal, method of dealing with endogeneity is to examine, for each council, the simple bivariate relationship between (i) the change in CEO pay over the sample period and (ii) the corresponding change in personnel cost. If the empire-building interpretation is correct, then (i) and (ii) should be predominately of the same sign, i.e., within each council, a rise (fall) in real per-capita personnel cost over the sample period should be associated with a corresponding increase (decrease) in real CEO pay.

This turns out to be the case: of the 45 councils that had a CEO serve at least three consecutive years during the sample period, 41 saw personnel cost and CEO pay move in the same direction. Moreover, as can be seen in Figure 1, bigger increases in personnel cost are, on average, associated with bigger increases in CEO pay.

Both this informal analysis and the formal Wooldridge (2010) test suggest that our primary results are not solely due to endogeneity problems.

${ }^{27}$ See Di Tella and Fisman (2004) for more discussion of this 'Position' hypothesis 
But nor do they definitively preclude the possibility that these results are the result of phenomena unrelated to empire building. For example, they may simply reflect the influence of some underlying variable that increases ratepayer demand for councilprovided services, with CEOs then being rewarded for meeting this demand. However, such arguments run into the problem of having to explain why the remuneration rewards appear to be solely for hiring more bureaucrats, and not, for example, for providing more infrastructure services, or organising more community events. It is by no means easy to imagine a variable that could rationally induce ratepayers to reward council CEOs for employing more bureaucrats but not at the same time also induce greater rewards for providing other highly-valued services.

Figure 1. 2006-10 changes. Scatterplot of change in real CEO pay and change in real personnel cost per head of population between 2006 and 2010 for the 45 councils that had a CEO serving at least three consecutive years during that period. The solid line represents the OLS regression fit.

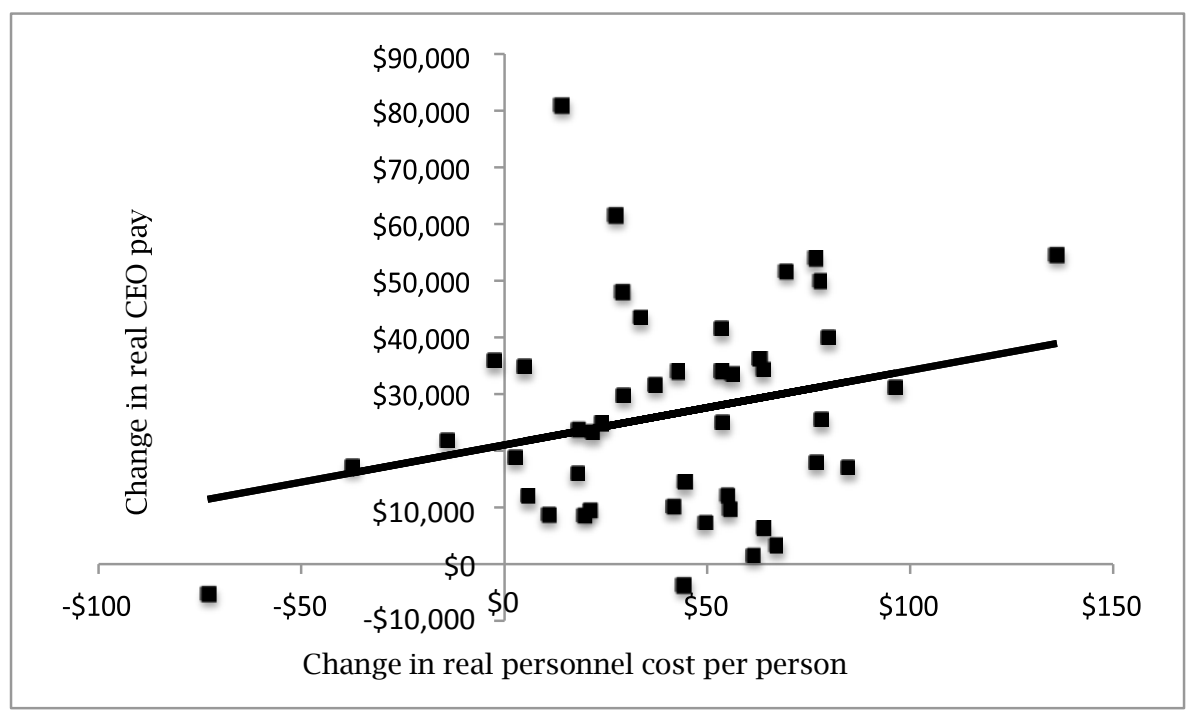

\section{CONCLUDING REMARKS}

Are bureaucrats actually paid in the manner traditionally associated with their position? Our sample of senior bureaucrats from NZ local government organisations suggests not. Instead, they appear to be rewarded for expanding the size of the organisations they manage. While we cannot definitively rule out the possibility that this indicates efficient compensation of CEOs who provide more and better ratepayer services, or face greater job complexity, the balance of our evidence is more consistent with the idea that the senior bureaucrats in our sample are, on average, rewarded for 'empirebuilding'.

Such a conclusion is unlikely to surprise many public choice researchers, but it provides empirical evidence where none previously existed. However, we have really only scratched the surface of the complexities of bureaucrat compensation; a number of questions remain. How, for example, does the use of compensation consultants affect pay outcomes, and does this mitigate or exacerbate any empire building tendencies? Do pay structures reflect the dominant political affiliation within the government? Does the uncertain tenure of their paymasters (politicians) allow bureaucrats to become entrenched more easily than their private sector counterparts? Answers to these and many other questions will help to elevate our understanding of bureaucrat pay to the same level as our current understanding of corporate sector pay.

\section{REFERENCES}

1. Ballantine, J., J. Forker, and M. Greenwood, 2008. The governance of CEO incentives in English NHS hospital trusts. Financial Accountability and Management 24, 385-410.

2. Bebchuk, L. and J. Fried, 2004. Pay Without Performance: The Unfulfilled Promise of Executive Compensation. Cambridge, MA: Harvard University Press.

3. Bertrand, M. and S. Mullainathan, 2000. Agents with and without principals. American Economic Review 90 (Papers and Proceedings), 203-208.

4. Birchfield, R., 2004. What's driving local government's management revolution? New Zealand Management 51, 45-48.

5. Boyle, G., 2008. Pay peanuts and get monkeys? Evidence from academia. The B.E. Journal of Economic Analysis \& Policy, 8, 1-24.

6. Brickley, J., and R. Van Horn, 2002. Managerial incentives in nonprofit organizations: evidence from hospitals. Journal of Law and Economics 45, 227-249.

7. Brickley, J., R. Van Horn, and G. Wedig, 2010. Board composition and nonprofit conduct: evidence from hospitals. Journal of Economic Behavior and Organisation 76, 196-208.

8. Cahan, S., F. Chua, and R. Nyamori, 2005. Board structure and executive compensation in the public sector: New Zealand evidence. Financial Accountability and Management 21, 437-465. 
9. Carsey, T., 2000. Campaign Dynamics: The Race for Governor. Ann Arbor, MI: The University of Michigan Press.

10. Crewson, P., 1997. Public-service motivation: building empirical evidence of incidence and effect. Journal of Public Administration Research and Theory 7, 499-518.

11. Di Tella, R., and R. Fisman, 2004. Are politicians really paid like bureaucrats? Journal of Law and Economics 47, 477-513.

12. Edmans, A. and X. Gabaix, 2009. Is CEO pay really inefficient? A survey of new optimal contracting theories. European Financial Management 15, 486496.

13. Fritsche, U. and F. Marklein, 2001. Leading indicators of Euroland business cycles. DIWDiskussionspapiere, No. 238.

14. Frydman, C. and D. Jenter, 2010. CEO compensation. Annual Review of Financial Economics 2, 75-102

15. Grofman, B., G. Owen, and C. Collet, 1999. Rethinking the partisan effects of higher turnout: so whats the question? Public Choice 99, 357-376.

16. Hall, B. and J. Liebman, 1998. Are CEOs really paid like bureaucrats? Quarterly Journal of Economics 113, 653-691.

17. Johnson, R., and G. Libecap, 1989. Agency growth, salaries and the protected bureaucrat. Economic Inquiry 27, 431-451.

18. Krystalogianni, A., G. Matysiak, and S. Tsolacos, 2004. Forecasting UK commercial real estate cycle phases with leading indicators: a probit approach. Applied Economics 36, 2347-2356.

19. Lynn, J., and A. Jay, 1984. The Complete Yes Minister. New York, NY: Harper \& Row.

20. Mueller, D., 2003. Public Choice III. Cambridge: Cambridge University Press.

21. Murphy, K., 2012. Executive compensation: where we are, and how we got there, George Constantinides, Milton Harris, and Ren Stulz (eds.),
Handbook of the Economics of Finance, Elsevier Science North Holland (Forthcoming). Available at SSRN: http://ssrn.com/abstract=2041679

22. Niemi, R., H. Weisberg, and D. Kimball, 2011. Controversies in Voting Behavior (5th Ed.). Washington DC: CQ Press.

23. Niskanen, W., 1975. Bureaucrats and politicians. Journal of Law and Economics 18, 617-643.

24. Perry, J., and L. Wise, 1990. The motivational bases of public service. Public Administration Review 50, 367-373.

25. Perry, J., A. Hondeghem, and L. Wise, 2010. Revisiting the motivational bases of public service: twenty years of research and an agenda for the future. Public Administration Review 70, 681-690.

26. Prendergast, C., 2007. The motivation and bias of bureaucrats. American Economic Review 97, 180196.

27. Rua, A. and L. Nunes, 2005. Coincident and leading indicators for the euro area: a frequency band approach. International Journal of Forecasting 21, 503-523.

28. Smith, N., 2012. Better local government reforms announced. Available at http://www.beehive. govt.nz/release/better-local-government-reformsannounced

29. Tuttle, M., and D. Bumpass, 2010. Factors influencing governors' salaries, 1961-2001. The B.E. Journal of Economic Analysis and Policy 10, Article 34.

30. Weatherby, J., 1971. A note on administrative behavior and public policy. Public Choice 11, 107110.

31. White, H., 1980. A heteroskedasticity-consistent covariance matrix estimator and a direct test for heteroskedasticity. Econometrica 48, 431-460.

32. Wooldridge, J., 2010. Correlated random effects models with unbalanced panels. Michigan State University working paper. 